\title{
ホタテ貝殼を活用したホタテ地まき漁場造成に ついて
}

\author{
CREATION OF THE JAPANESE SCALLOP SOWING FISHING GROUND USED \\ ITS SHELL FRAGMENT
}

\author{
伊藤靖 1 ・吉野真史 ${ }^{1} \cdot$ 酒向章哲 $2 \cdot$ 櫻井泉 $3 \cdot$ 西田芳則 4 ・新山伸二 5 \\ Yasushi ITO, Masafumi YOSHINO, Akinori SAKO, Izumi SAKURAI, Yoshinori NISHIDA and \\ Shinji NIIYAMA

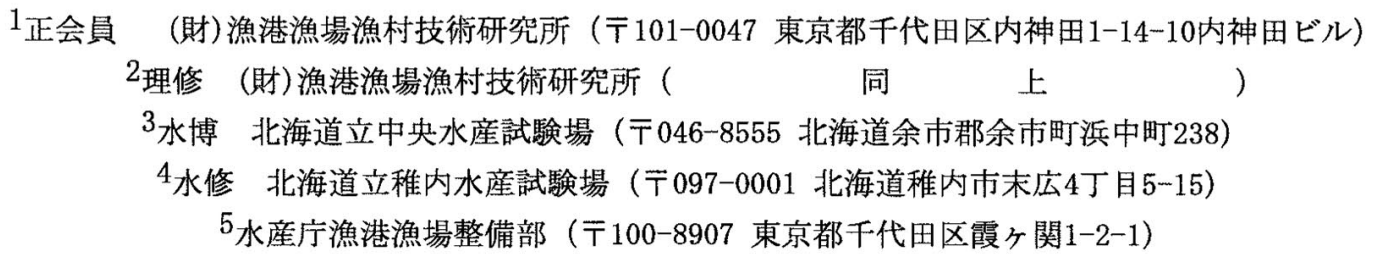

In this study, we developed a method of the Japanese scallop sowing fishing ground creation used the scallop shell fragment. To evaluate the significance of scallop production and the influence on environment, we investigated scallop growth, and water and sediment qualities after laying the shell fragment on the fishing ground. In addition, we examined hydrodynamic stability of the shell fragment under laboratory condition. The results indicated that the shell fragment laying had significant effect to the scallop growth with no bad influence on water and sediment qualities. Furthermore, we proposed a selection method of suitable conditions which the shell fragment would be stable on the fishing ground.

Key Words : scallop, scallop shell, fishing ground, stability of scallop shell, water and sediment qualities, scallop growth

\section{1.はじめに}

北海道におけるホタテガイ生産は 40 万トンを超 え, 生産量, 生産額共に全国第一位の座を占め, 北 海道における水産業の柱となっているものの，生産 に伴い大量に排出される貝殸の処理が大きな問題と なっている.そして，環境保全や環境との調和に対 する国民的ニーズの高まりやバイオマス利用の観点 から，ホタテ貝殼の有効活用は喫緊に対応すべき重 要な課題となっている. また, ホタテガイは一般に バラス場と呼ばれる底質が砂混じりの砂で構成され る場において成長が良化することが知られているが， 北海道オホーツク海においては砂泥域が多く, 漁場 改良による生産性の向上や未利用海域における漁場 造成が強く求められている。

本研究は, 泥が厚く堆積して生産性が低い北海道 オホーツク海沿岸ホタテ地まき放流漁場を対象に, 水質環境への影響，貝殼片の安定性，ホタテガイの 成長良化に着目して，ホタテ貝殼散布による漁場造 成技術を開発することを目的として行った。

\section{2. 調査内容}

\section{(1) 調查の概要}

前述のとおり，ホタテはバラス場と呼ばれる礫分 を主とした底質上で生息密度が高く，シルトが多い 底質上では低い事が知られている ${ }^{11,2)}$. そのため, 地撒き放流漁業を営む北海道才ホーツク沿岸各漁協 は，バラス場形成を目的に貝款をシルトが多い底質 上に散布した後稚貝を放流する試験を実施しており， 漁場改良効果も散見されている. 雄武漁協の試験 ${ }^{3)}$ では，放流貝の成長良化，天然貝発生率の上昇，漁 獲効率の向上及び漁獲時の割れ貝減少の報告がある. 図-1にホタテ貝殼散布による漁場造成効果のイ メージを示す.

しかしながら，ホタテ貝殸散布に対しては付着有 機物による水質・底質の悪化や波浪や流動による散 逸が懸念されるため, 安全性を確認した上で事業を 実施する必要がある．以上に鑑み，本研究において は，図-2 に示すホタテ地撒き漁業が盛んな北海道 オホーツク海沿岸の雄武, 枝幸海域を対象として調 
查を実施した。 また，ホタテ貝款の安定性について は, 振動流水槽による室内水槽実験で調査を実施し た. 調査の概略を表-1 に示す.

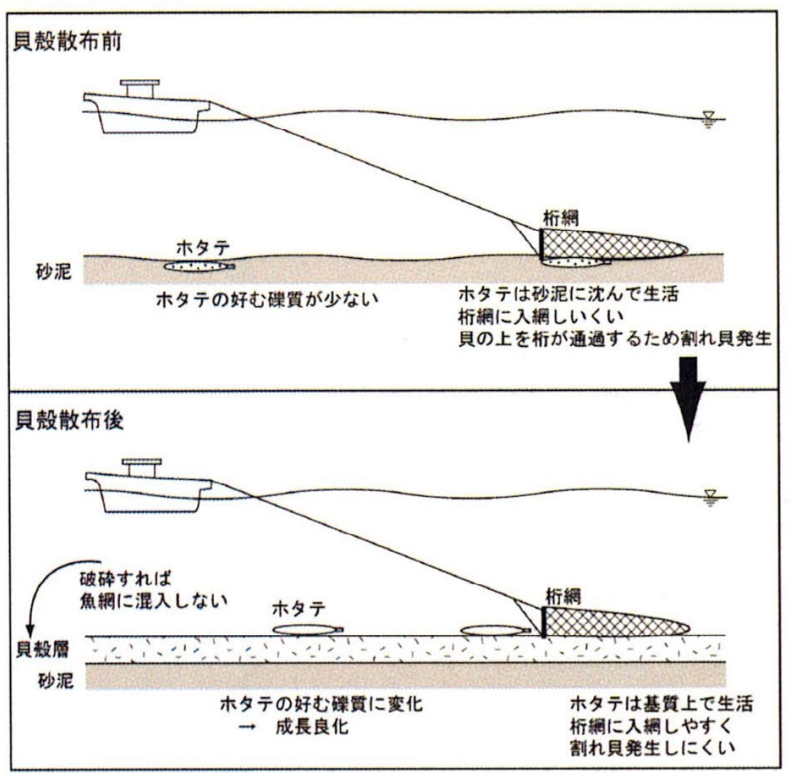

図-1 ホタテ貝殼散布による漁場造成効果のイメージ

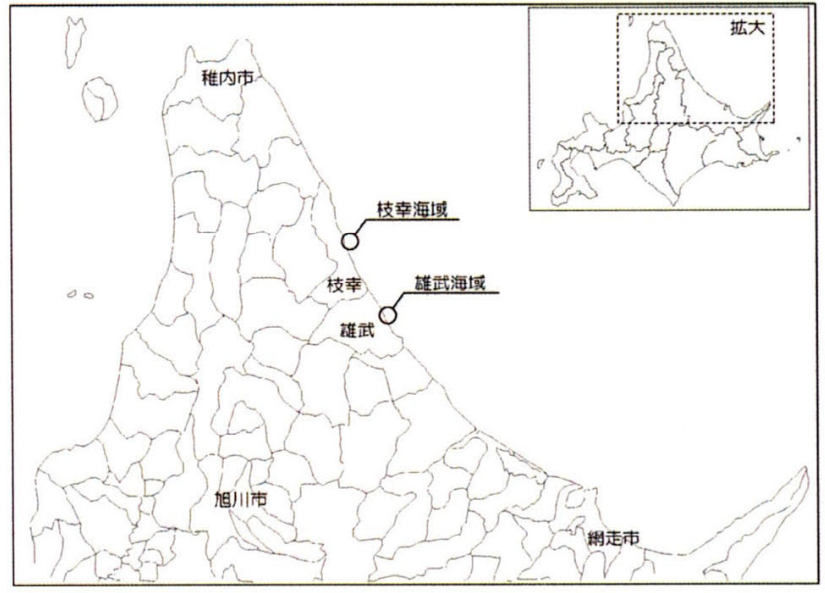

図-2 調査海域位置図

表-1 調査項目と対象位置

\begin{tabular}{|l|c|}
\hline \multicolumn{1}{|c|}{ 調査項目 } & 対象位置 \\
\hline $\begin{array}{l}\text { ホタテ貝殼散布による水質・底質 } \\
\text { リスク調査 }\end{array}$ & 雄武海域 \\
\hline ホタテ貝殼片安定性調査 & 室内水槽実験 \\
\hline $\begin{array}{l}\text { ホタテ貝殼散布がホタテガイ成長 } \\
\text { に与える効果調查 }\end{array}$ & 枝幸海域 \\
\hline
\end{tabular}

（2）貝殻散布の水質・底質リスクの検討

\section{a）ホタテ貝殼散布}

雄武町沿岸の水深 $30 \mathrm{~m}$ 海域を対象として, 平成 16 年 9 月 2 日〜 6 日にホタテ貝殼を散布した. 写 真-1 にホタテ貝款散布作業を, 写真-2 に散布後の 海底の状況を示す．散布範囲は図-3 に示すとおり， 目標層厚 $4 \mathrm{~cm}$ 区域を $165 \mathrm{~m} \times 88 \mathrm{~m}$, 目標層厚 $2 \mathrm{~cm}$ 区域 を $160 \mathrm{~m} \times 128 \mathrm{~m}$ とし，投入時の潮流による移動を勘
案して目標層厚の 2 倍程度の量である $2,039 t$ のホ タテ貝殼を散布した。 ホタテ貝殼は堆積場にて風雨 に 1 年間以上さらして十分に風化させた上で，粒径 $3 \mathrm{~cm}$ 程度まで破砕して使用した。 ホタテ貝殼の風化 の度合いについては，宗谷管内ホタテ貝殼有効利用 協議会にて参考基準として溶出試験にて BOD 濃度が

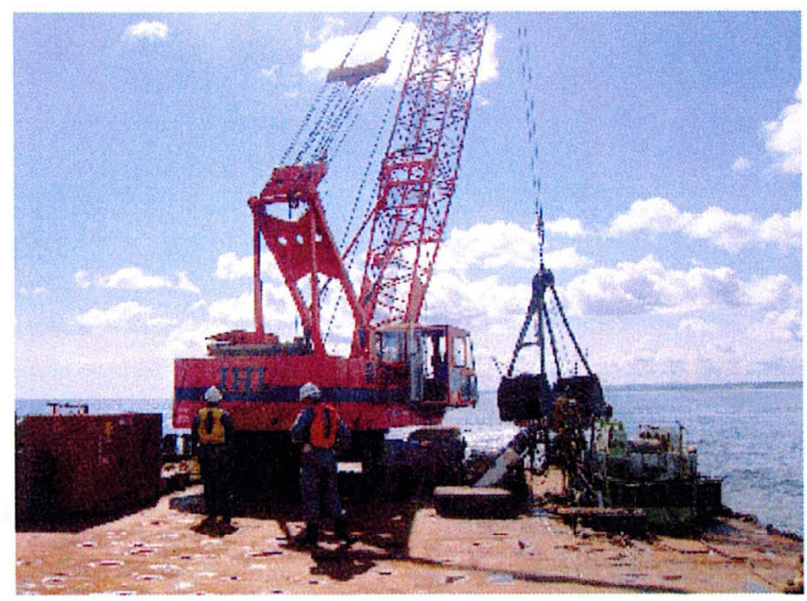

写真-1 ホタテ貝殼散布作業

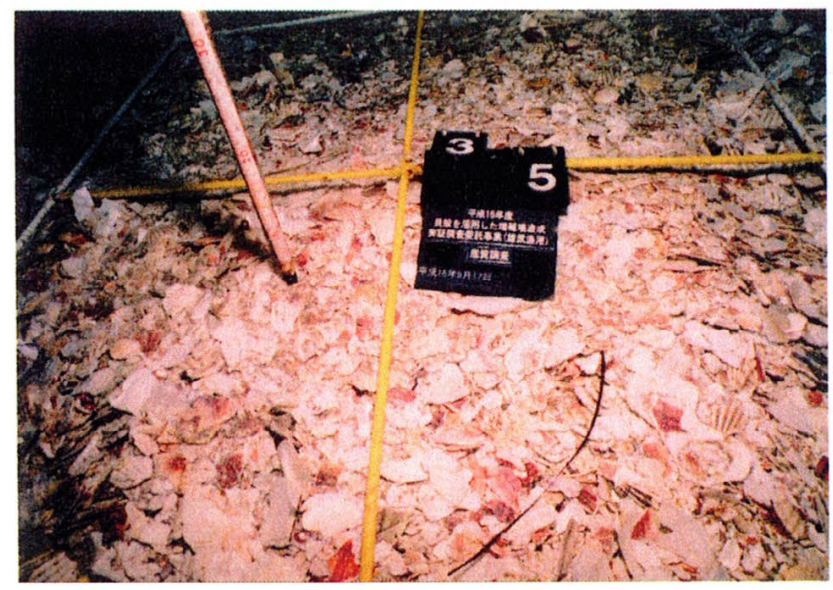

写真-2 ホタテ貝殸散布後の海底状況

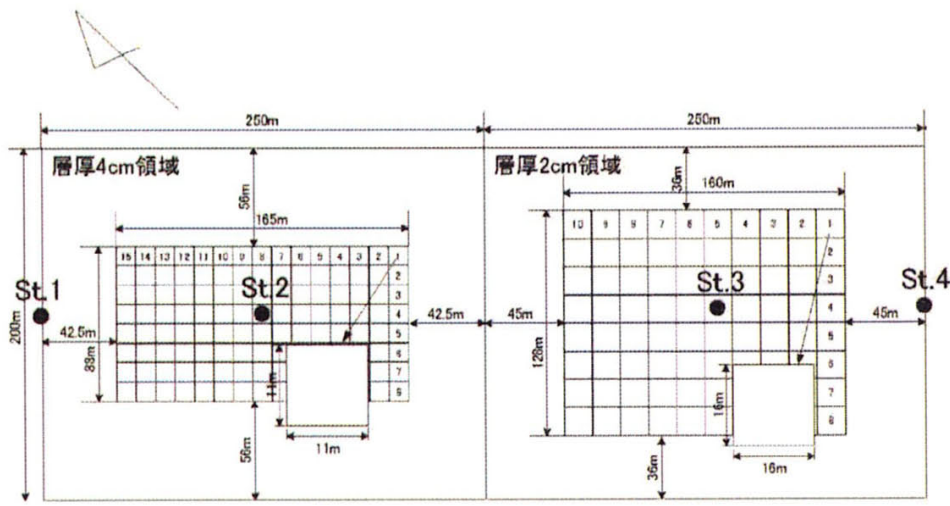

図-3 貝款散布区域および水質・底質調查地点

$2 \mathrm{mg} / \mathrm{L}$ 以内とされており ${ }^{4)}$, その基準を満足するこ とを確認した上で散布を実施した.

b) 水質 ·底質調査

前述のとおりホタテ貝款散布は平成 16 年 9 月 2 
日〜6 日に実施したが，散布直前（8月 21 日），散 布直後（9月 7 日），散布 10 日後（9月 17 日）に 水質・底質調査を実施した。調査地点は，水質調查 は図-3 の St. 1〜St. 4, 底質調査は St. 2 である.

表-2 に水質調査結果を, 表-3 に底質調査結果をそ れぞれ示す。

水質については，化学的酸素要求量 (COD)および 浮遊懸濁物質 (SS) はいずれも全て定量限界末満であ り，有機物や浮遊懸濁物質の溶出は見られず，ホタ テ貝殼散布前の良好な水質がそのまま維持されてい ると考えられる。また, 溶存酸素濃度 (D0) はホタテ 貝殸散布直後に $0.5 \mathrm{mg} / \mathrm{L}$ 程度低下しているが，散布 10 日後には表層の濃度が回復していることや，い ずれにおいても水産用水基準 $6.0 \mathrm{mg} / \mathrm{L}$ を満足してい ることから，ホタテ貝款の散布が水質環境に与える 負荷は少ないと考えられる。

表-2 ホタテ貝殼散布前後の水質分析結果

\begin{tabular}{|c|c|c|c|c|c|c|c|c|c|c|}
\hline \multirow{3}{*}{\multicolumn{2}{|c|}{$\begin{array}{c}\text { 分析項目 } \\
\text { 単位 } \\
\text { 調査地点、 } \\
\text { 水深 }\end{array}$}} & \multirow{2}{*}{\multicolumn{3}{|c|}{$\begin{array}{l}\mathrm{COD}_{\mathrm{OH}} \\
\mathrm{mg} / \mathrm{L}\end{array}$}} & \multirow{2}{*}{\multicolumn{3}{|c|}{$\begin{array}{c}\mathrm{SS} \\
\mathrm{mg} / \mathrm{L}\end{array}$}} & \multicolumn{3}{|c|}{ D0 } \\
\hline & & & & & & & & & $\mathrm{mg} / \mathrm{L}$ & \\
\hline & & \multirow{2}{*}{$\begin{array}{l}8 / 21 \\
<0.5\end{array}$} & \multirow{2}{*}{$\begin{array}{l}9 / 7 \\
<0.5\end{array}$} & \multirow{2}{*}{$\begin{array}{l}9 / 17 \\
<0.5\end{array}$} & \multirow{2}{*}{$\begin{array}{c}8 / 21 \\
<1\end{array}$} & \multirow{2}{*}{$\begin{array}{r}9 / 7 \\
<1\end{array}$} & \multirow{2}{*}{$\begin{array}{c}9 / 17 \\
<1\end{array}$} & \multirow{2}{*}{$\begin{array}{l}8 / 21 \\
8.4\end{array}$} & \multirow{2}{*}{$\begin{array}{l}9 / 7 \\
7.6\end{array}$} & \multirow{2}{*}{$\begin{array}{l}9 / 17 \\
8.1\end{array}$} \\
\hline \multirow{3}{*}{$\begin{array}{c}\text { St. } 1 \\
32 \mathrm{~m}\end{array}$} & 表層 & & & & & & & & & \\
\hline & 中層 & $<0.5$ & $<0.5$ & $<0.5$ & $<1$ & $<1$ & $<1$ & 8.6 & 7.6 & 7.5 \\
\hline & 底層 & $<0.5$ & $<0.5$ & $<0.5$ & $<1$ & $<1$ & $<1$ & 8.1 & 7.5 & 7.5 \\
\hline \multirow{3}{*}{$\begin{array}{c}\text { St. } 2 \\
32 \mathrm{~m}\end{array}$} & 表層 & $<0.5$ & $<0.5$ & $<0.5$ & $<1$ & $<1$ & $<1$ & 8.6 & 7.6 & 8.0 \\
\hline & 中層 & $<0.5$ & $<0.5$ & $<0.5$ & $<1$ & $<1$ & $<1$ & 8.4 & 7.5 & 7.6 \\
\hline & 底層 & $<0.5$ & $<0.5$ & $<0.5$ & $<1$ & $<1$ & $<1$ & 8.2 & 7.5 & 7.5 \\
\hline \multirow{3}{*}{$\begin{array}{c}\text { St. } 3 \\
30 \mathrm{~m}\end{array}$} & 表層 & $<0.5$ & $<0.5$ & $<0.5$ & $<1$ & $<1$ & $<1$ & 8.2 & 7. 6 & 8.0 \\
\hline & 中層 & $<0.5$ & $<0.5$ & $<0.5$ & $<1$ & $<1$ & $<1$ & 8.1 & 7.4 & 7.5 \\
\hline & 底層 & $<0.5$ & $<0.5$ & $<0.5$ & $<1$ & $<1$ & $<1$ & 8.1 & 7.5 & 7.6 \\
\hline \multirow{3}{*}{$\begin{array}{c}\text { St. } 4 \\
31 \mathrm{~m}\end{array}$} & 表層 & $<0.5$ & $<0.5$ & $<0.5$ & $<1$ & $<1$ & $<1$ & 8.2 & 7.6 & 8.5 \\
\hline & 中層 & $<0.5$ & $<0.5$ & $<0.5$ & $<1$ & $<1$ & $<1$ & 8.4 & 7.6 & 7.5 \\
\hline & 底層 & $<0.5$ & $<0.5$ & $<0.5$ & $\langle 1$ & $<1$ & $<1$ & 7.8 & 7.5 & 7.4 \\
\hline
\end{tabular}

底質については, 強熱減量と全窒素は散布前後で 変化が無く, 底質に有機物が添加された状況は見ら れなかった．全炭素については散布後に非常に大き な值を示すが, これはホタテ貝殼の主成分が炭酸力 ルシウムであることによると考えられる.

表-3 ホタテ貝殸散布前後の底質分析結果

\begin{tabular}{|c|c|c|c|c|c|c|c|c|c|}
\hline 分析項目 & \multicolumn{3}{|c|}{ 強熱减量 } & \multicolumn{3}{c|}{ 全窒素 } & \multicolumn{3}{c|}{ 全炭素 } \\
\hline $\begin{array}{c}\text { 単位 } \\
\text { 調查地点、 } \\
\text { 水深 }\end{array}$ & $8 / 21$ & $9 / 7$ & $9 / 17$ & $8 / 21$ & $9 / 7$ & $9 / 17$ & $8 / 21$ & $9 / 7$ & $9 / 17$ \\
\hline $\begin{array}{c}\text { St. } 2 \\
32 \mathrm{~m}\end{array}$ & 1.20 & 欠 & 1.11 & $<0.1$ & $<0.1$ & $<0.1$ & 0.1 & 11.4 & 11.0 \\
\hline
\end{tabular}

以上の結果から，十分に風化されたホタテ貝殼の 散布が水質・底質環境に与える影響は非常に小さい と結論付けられる。

\section{（2）ホタテ貝殼片の安定性検討}

\section{a）実験手順}

実験には，粒径を 6 段階に破砕したホタテ貝殼片 を使用した。実験に用いた振動流水槽（観測部：長 さ $1.5 \mathrm{~m}$, 幅 $0.3 \mathrm{~m}$, 深さ $0.35 \mathrm{~m})$ を図 -4 に示す.こ の水槽は全体が環状構造を有しており，下部中央部
に内蔵されたプロペラをモーターで駆動することに よって振動流を発生できる仕組みとなっている. 水 槽底部には，市販の珪砂を敷設し，その上に写真-3 に示すように貝殼片を長さ $80 \mathrm{~cm}$, 厚さ $5 \mathrm{~cm}$ に敷き 詰めた。 その後に水槽内にろ過海水を満たした状態 で流れを発生させ，貝殼片の挙動をビデオカメラで 記録した。珪砂の中央粒径は 5 段階とし，敷設後の 砂面形状は平坦な状態と砂漣が形成された状態の 2 パターンとした. 流れの状態は, 周期 4〜 12 秒で, 流速振幅 8〜 96cm/s とした. 貝款片のサイズ, 底質 粒径および実験条件の組み合わせは表-4 に示すと おりで，計 30 回の実験を実施した。表-4 中の数值 は振動流の周期（秒），F は平坦な状態， R は砂漣 が形成された状態を示す。

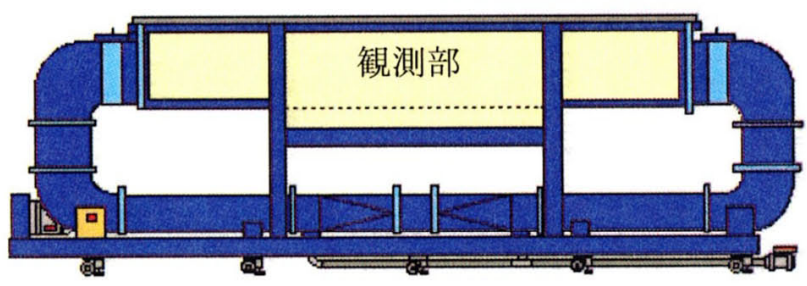

図-4 振動流水槽の概要

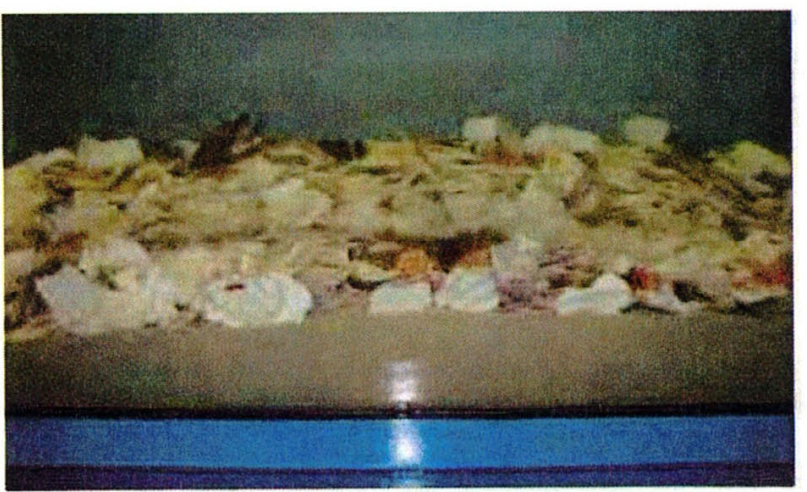

写真-3 貝殼片 $(11.2 \sim 22.4 \mathrm{~mm})$ の敷設状況

表-4 実験条件の組み合わせ

\begin{tabular}{|c|c|c|c|c|c|}
\hline \multirow{2}{*}{$\begin{array}{c}\text { 貝殼サイズ } \\
(\mathrm{mm})\end{array}$} & \multicolumn{5}{|c|}{ 底質粒径 $(\mathrm{mm})$} \\
\cline { 2 - 6 } & 0.063 & 0.125 & 0.250 & 0.550 & 1.000 \\
\hline $4.75 \sim 11.2$ & $4 \mathrm{~F}$ & $6 \mathrm{R}$ & $8 \mathrm{~F}$ & $10 \mathrm{R}$ & $12 \mathrm{~F}$ \\
\hline $11.2 \sim 22.4$ & $6 \mathrm{~F}$ & $8 \mathrm{R}$ & $10 \mathrm{~F}$ & $12 \mathrm{R}$ & $4 \mathrm{~F}$ \\
\hline $22.4 \sim 31.5$ & $8 \mathrm{~F}$ & $10 \mathrm{R}$ & $12 \mathrm{~F}$ & $4 \mathrm{R}$ & $6 \mathrm{~F}$ \\
\hline $31.5 \sim 37.5$ & $10 \mathrm{~F}$ & $12 \mathrm{R}$ & $4 \mathrm{~F}$ & $6 \mathrm{R}$ & $8 \mathrm{~F}$ \\
\hline $37.5 \sim 53.0$ & $12 \mathrm{~F}$ & $4 \mathrm{R}$ & $6 \mathrm{~F}$ & $8 \mathrm{R}$ & $10 \mathrm{~F}$ \\
\hline $53.0 \sim 75.0$ & $4 \mathrm{~F}$ & $6 \mathrm{R}$ & $8 \mathrm{~F}$ & $10 \mathrm{R}$ & $12 \mathrm{~F}$ \\
\hline
\end{tabular}

\section{b）安定性評価のパラメータ}

流れに対する貝殼片の安定性を評価するため，本 実験では流速と貝殼片の沈降速度比およびシールズ 数をパラメータとして算出した.

貝殼片の沈降速度 $w$ に対する流速 $u$ の比 $u / w$ につ いては, 值が小さければ貝殼片は沈降しやすく安定 的となるが, 大きければ逆に流動的となる. 沈降速

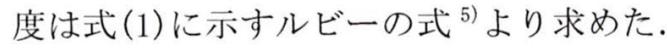




$$
w=\sqrt{(s-1) g d} \times\left(\sqrt{\frac{2}{3}+\frac{36 v^{2}}{(s-1) g d^{3}}}-\sqrt{\frac{36 v^{2}}{(s-1) g d^{3}}}\right)
$$

ここに, $s$ は貝殸片の比重, $v$ は水の動粘性係数, $d$ は貝款片の代表粒径, $g$ は重力加速度, である.

シールズ数 $\psi$ は流れや波の場において砂粒子の 動きやすさを表すパラメータであり，本調査では式 (2)により算出した.

$$
\psi=\frac{f u^{2}}{2(s-1) g d}
$$

ここに, $f$ は Jonsson の摩擦係数である.

\section{c）貝殻片の挙動と流れの関係}

流れに対する貝殸片の挙動は, 以下の 4 パターン に区別できた。

O型（不動）：貝殼片は動摇せず安定している

I 型（微動）：一部の貝殼片が動摇するが，移動 は認められない

II 型（転動）：殆どの貝款片が動摇すると共に， 一部の貝款片が底面上を転動する

III型（集積・埋没）：半数以上の貝殼片が底面上 を転動した後，各々が直立し安定す る

図-5に流速／沈降速度比，シールズ数および貝 款片挙動パターンの関係を示す。図-5 によると, 各々の挙動パターンは一部が重複するものの，明瞭 に区分された。そこで，各挙動パターンの境界を流 速/沈降速度比とシールズ数の関係で表-5 のよう に表現した。なお，珠砂ではなくサンドペーパーを 敷設した予備実験では貝殼片が浮遊移動するIV 型

（流失）も認められたが，砂を敷設した実験では砂 の混入により水槽駆動部が破損する危険性があるた め, IV 型の発生を確認できる流動条件を与えること ができなかった。このため, IIII型とIV型の境界につ いては予備実験の結果を使用した.

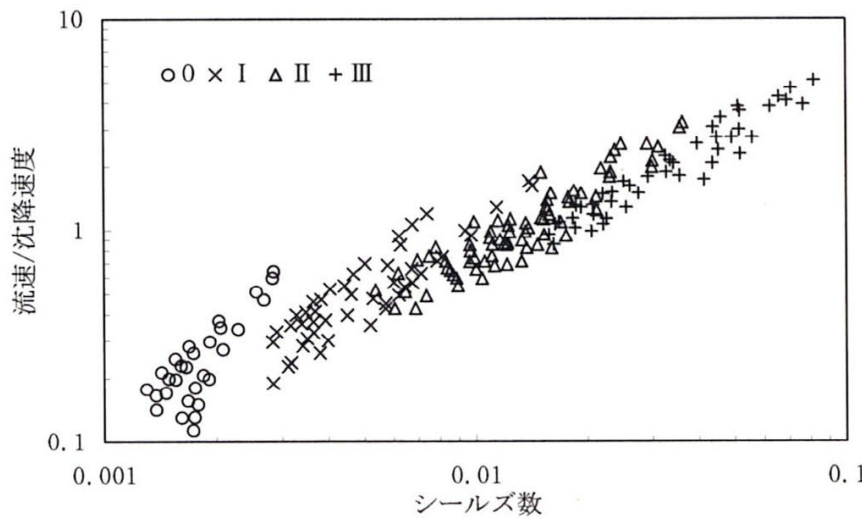

図-5 流速沈降速度比，シールズ数および貝款片挙動 パターンの関係

表-5 各挙動パターンの境界を示す流速沈降速度比と
シールズ数の関係式

\begin{tabular}{|c|c|}
\hline 境界 & 関倸式 \\
\hline 0 型 $:$ I 型 & $u / w=e^{18.06} \psi^{3.16}$ \\
\hline I 型 $:$ II 型 & $u / w=e^{6.96} \psi^{1.51}$ \\
\hline II 型 $:$ III型 & $u / w=e^{6.71} \psi^{1.67}$ \\
\hline III 型 $:$ IV 型 & $u / w=e^{4.77} \psi^{1.33}$ \\
\hline
\end{tabular}

表-5 に示した関係式を基に挙動パターンの判定 条件を図化したのが図-6 である，今後の事業計画 策定にあたっては，設計波高から微小振幅波理論に よって求められた流速, 式(1)から求めた沈降速度, 式(2)から求めたシールズ数を基に図-6 を利用して 貝殼片の安定性を評価できることとなる.

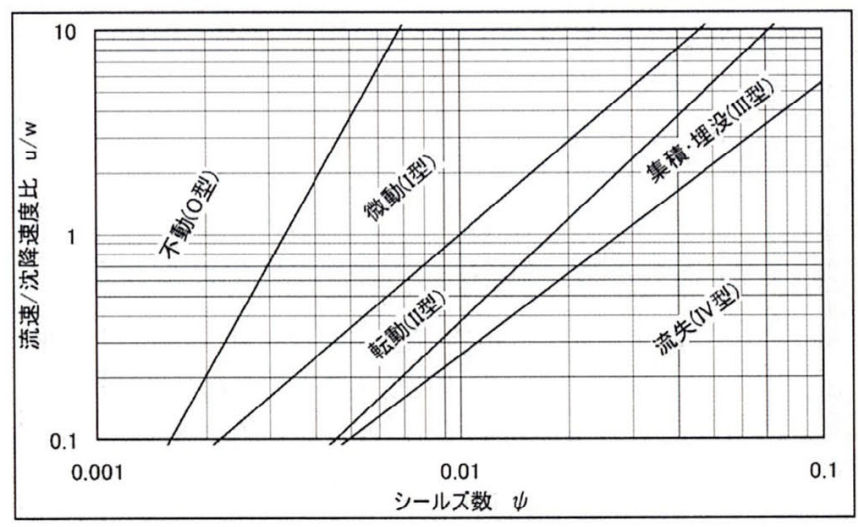

図-6 貝殸片の安定性の判定条件

（3）貝殼散布がホタテガイの成長に与える効果 a) 調査区域

調查海域は, 図-2 に示した枝幸町地先の水深 $30 \mathrm{~m}$ の地域とした。試験区域の概念は図-7 に示寸とお りであり, 平成 13 年から平成 15 年まで 3 年間に 渡って枝幸漁業協同組合が貝殼の散布を実施してい る. 本調查においては, 平成 14 年に貝殼を散布し た実験区 1 , 平成 15 年に貝殼を散布した実験区 2 , 貝款散布区域外の対照区の計 3 試験区域を対象とし て平成 16 年 6 月にホタテガイ稚貝を散布し, ホタ テガイの成長調査を実施した。なお，平成 18 年 6 月に貝款の層厚を調查した結果，砂と貝殼が混じり 合った状態ではあるものの，実験区 1 で $8.3 \mathrm{~cm}$ ，実 験区 2 で $15.0 \mathrm{~cm}$ を示し, 散布から約 3 年以上が経 過しても貝殼が存在していることが確認された.

b）ホタテガイ成長調査

前述のようにホタテガイ稚貝は平成 16 年 6 月に 放流されており, 2 年後の平成 18 年 7 月までに 6 回採取を実施した。各調查区域においてホタテガイ を区域ごとに 50 個体程度採取し成長を測定した。 


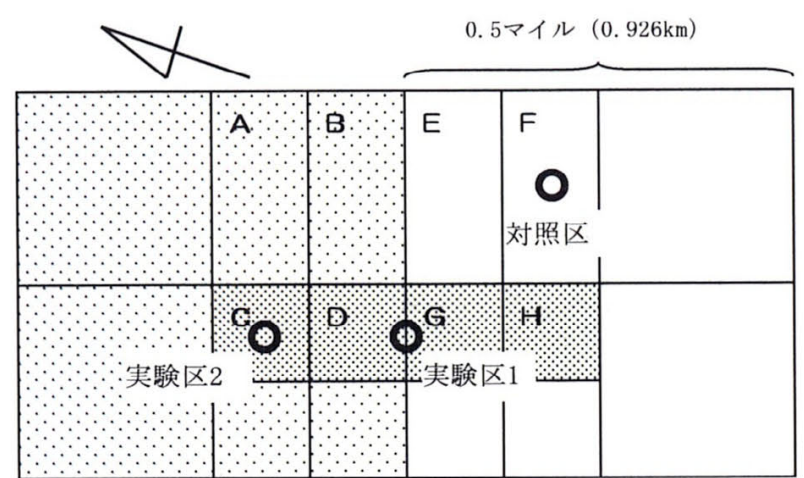

$\bigcirc$ : 調查実施箇所

$\mathrm{A}, \mathrm{B}$ 区：平成13年度散布区（層厚約 $8 \mathrm{~mm}$ ） C, D区：平成14, 15 年度散布区（層厚約 $45 \mathrm{~mm}$ )

$G, H$ 区：平成 15 年度散布区（層厚約 $25 \mathrm{~mm}$ ） E, F区：対照区 (未散布区)

図-7 試験区域概念図

平成 18 年 7 月採取ホタテガイの測定結果を表-6 に示す.殼高と 2 齢時の障害輪高との差から殼の伸 び率を測定したところ実験区 1 と実験区 2 のホタテ ガイの款伸率は $10 \%$ 以上になっており，これは対照 区と比して良好な結果である。これについては Kruskal-wallis 検定を行ったところ区画間で殼伸率 に有意差があると判定された。

表-5 各試験区にて採取されたホタテガイの成長（平成 18 年 7 月)

\begin{tabular}{|c|c|c|c|c|c|}
\hline & 項目 & 単位 & 実験区1 & 実験区2 & 対照区 \\
\hline & 障害輪高 (0齢) & $\mathrm{mm}$ & 39.3 & 37.9 & 43.4 \\
\hline & 障害輪高 (2齢) & $\mathrm{mm}$ & 100.6 & 99.4 & 102.2 \\
\hline & 殸高 & $\mathrm{mm}$ & 112.6 & 113.5 & 111.8 \\
\hline & 殸伸率 (0齢～) & $\%$ & 64.9 & 66.6 & 61.2 \\
\hline & 殸伸率 (2齢〜) & $\%$ & 11.9 & 14.2 & 9.4 \\
\hline \multirow{4}{*}{ 重量 } & 全重量 & $\mathrm{g}$ & 120.4 & 120.2 & 115.6 \\
\hline & 軟体部 & g & 56.8 & 58.5 & 55.9 \\
\hline & 款 & $\mathrm{g}$ & 63.5 & 61.6 & 59.6 \\
\hline & 貝柱 & $\mathrm{g}$ & 24.0 & 25.2 & 22.9 \\
\hline 軟体部 & 歩留まり & $\%$ & 47.2 & 48.5 & 48.4 \\
\hline \multirow[t]{3}{*}{ 貝柱 } & 水分含量 & $\%$ & 72.9 & 72.6 & 73.1 \\
\hline & 欠刻内着率 & $\%$ & 12.8 & 11.7 & 16.0 \\
\hline & 分布密度 & $/ \mathrm{m}^{2}$ & 0.4 & 0.9 & 1.4 \\
\hline
\end{tabular}

1 齢から 5 齢までのホタテガイにおいては，年齢 と全重量の関係が線形なので ${ }^{6)}$, 年間の成長量は年 齢を問わず一定になる。そこで，平成 16 年 6 月（1 齢）と翌平成 17 年 6 月（2 齢）のデータを用いて, この期間の重量差から日間成長量を算出した。 ホタ テガイの成長は冬季に停滞するので, ホタテガイの 成長期間を 3 月 1 日〜9 月 30 日までとし, 重量差 を日数で除した. 各試験区域の日間成長量，および 対照区に対する実験区の増重率を表-6 に示す。日 間成長量は実験区 2 , 実験区 1 , 対照区の順に大き かった，対照区に対する増重率は実験区 1 で $8.7 \%$, 実験区 2 で $18.5 \%$ であり，平均で $13.6 \%$ と大きな増
重率を示した。

表-6 1 齢, 2 齢ホタテガイ全重量から推定した日間成長 量と対照区に対する実験区の増重率

\begin{tabular}{|c|c|c|c|}
\hline & 成長量 $(\mathrm{g}) \% 1$ & 日間成長量 $(\mathrm{g} / \text { 日 })^{* 2}$ & 増重率 (\%) \\
\hline 対照区 & 47.6 & 0.242 & \\
\hline 実験区1 & 51.7 & 0.262 & 8.7 \\
\hline 実験区2 & 56.4 & 0.286 & 18.5 \\
\hline 平均 & & & 13.6 \\
\hline
\end{tabular}

次に，日間成長量を基に推定した各試験区域にお ける年齢別全重量を表-7 に示す. なお, 当該海域 の漁期の中間月が 8 月なので，表には各年 8 月時点 での全重量を示した．対照区における 4 齢時の重量 は $174.5 \mathrm{~g}$ であり, この地区で漁獲されるホタテガ イの平均的な重量約 $170 \mathrm{~g}$ とほぼ一致する. 従って, 日間成長量で全重量を推定する手法は概ね妥当と考 えられる。

表-7 日間成長量から推定した各試験区域のホタテガ

\begin{tabular}{ccccc}
\multicolumn{4}{c}{ イ年齢別全重量 } \\
\hline 年齢 & 1 & 2 & 3 & 4 \\
\hline 対照区 & $22.3 \mathrm{~g}$ & $73.1 \mathrm{~g}$ & $123.8 \mathrm{~g}$ & $174.5 \mathrm{~g}$ \\
実験区1 & $24.3 \mathrm{~g}$ & $79.4 \mathrm{~g}$ & $134.5 \mathrm{~g}$ & $189.6 \mathrm{~g}$ \\
実験区 2 & $26.1 \mathrm{~g}$ & $86.3 \mathrm{~g}$ & $146.4 \mathrm{~g}$ & $206.5 \mathrm{~g}$ \\
\hline
\end{tabular}

※1年の成長期間を 210 日として各年齢8月時点での重量

\section{c）成長良化の考察}

最初に述べたように，ホタテガイの生息環境とし てバラス場が望ましいとされる。一方，砂泥域に分 布するホタテガイは, 海底に埋まって生息しており, 成長も悪い，貝殼片を海底に敷き詰めるということ は，ホタテガイが海底に潜り込みにくい環境を提供 することを意味する. 写真-4 にホタテ貝款上に存 在するホタテガイを，写真 -5 に海底に埋没してい るホタテガイをそれぞれ示す.

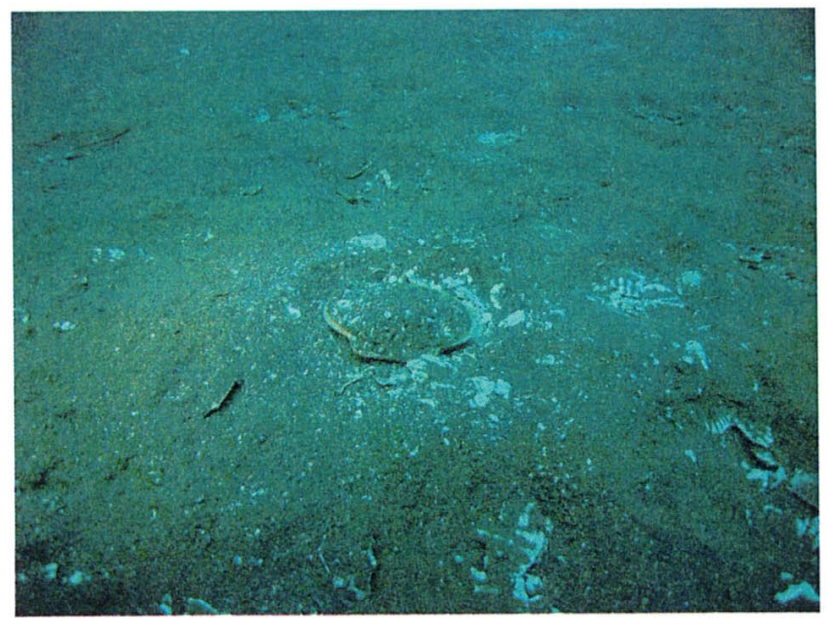

写真-4 ホタテ貝殸上に生息するホタテガイ 


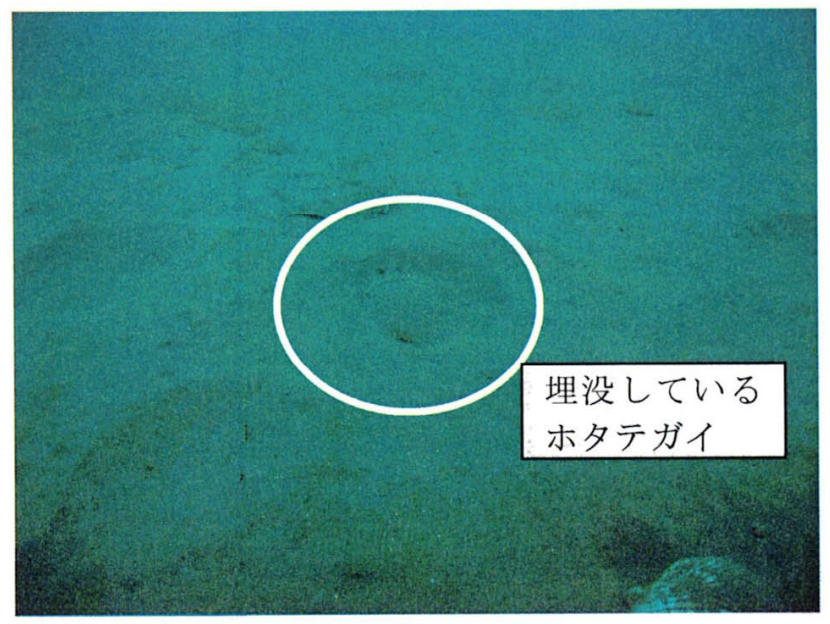

写真-5 海底に埋没しているホタテガイ

ホタテガイの成長は，流れに対するホタテガイの 定位方向により異なり，腹側を流れに向けたホタテ ガイの成長は背側を流れに向けたものよりも良いこ

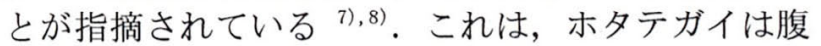
側から入水し背側から出水するため, 腹（入水）側 を流れに向けた方がエネルギーのロスがなく, 効率 よく摂慨できるためと報告 ${ }^{9)}$ されている.このよう に，流れがホタテガイの摂䬣効率に影響を与えるの は，ホタテガイの海水の吸引能力が低いこと（自ら 滤水できる範井は貝款縁辺部から数ミリ程度）から も理解できる. 流れの観点から貝款散布区と砂泥区 を比較すると, 貝殼散布区のホタテガイは海底に埋 もれていないため, 海底上の流れを直接利用できる と考えられる. 従って, 埋没, 海底上という生息様 式の違いが滤水率に反映し, 成長差が生じると推察 される。

\section{3.まとめ}

本研究で得られた成果を以下にまとめて示す.

(1)十分に風化されたホタテ貝殼の散布が水質・底 質環境に与える影響は非常に小さいことがわ かった。

(2)流速／沈降速度比とシールズ数をベースにした， 流れに対するホタテ貝殼片の安定性評価手法を 提案した。

(3)ホタテ貝殼散布漁場においては，ホタテガイは 敷設された貝殼の上に生息するので捸餌が促進 され，成長率が向上することがわかった。

\section{4. おわりに}

本研究において，ホタテ貝殼を活用したホタテ地 まき放流漁場造成に関する水質・底質環境に対する 安全性，および成長に対する有効性については概ね 確認されたが，実際に事業に適用するにあたっては 海域ごとの環境の特性に十分配虑し，水質・底質に ついては必要に応じてモニタリングを継続すべきと 考えられる.また，ホタテガイの成長については， 今後データを収集し，より精度の高い成長率を求め てゆく必要があると考えられる。

謝辞：本研究は，「貝殼を活用した増養殖場造成実 証調查委託事業」（水産庁漁港漁場整備部）により 実施された。研究の実施にあたっては「貝款を活用 した増養殖場造成実証調査委託事業協議会」（委員 長：長野章公立はこだて未来大学教授）の指導を受 けた. 北海道水産振興課, 水産経営課, 各水産試験 場の諸氏からは貴重な助言を頂戴した，枝幸，雄武 両漁業協同組合には現地調査に関して御協力賜った. ここに記して満腔の感謝の意を表す.

\section{参考文献}

1) 中川義彦, 和久井卓哉：常呂海域ホタテガイ漁場の底 質と大型底生動物について, 北水試月報, 32(3), pp. 16-30, 1975.

2) 中川義彦, 和久井卓哉 : 斜里・網走海域ホタテガイ漁 場の底質と大型底生動物について, 北水試月報, 33 (2), pp. 23-33，1976.

3) 雄武漁業協同組合：底質改良試験事業報告書 平成 10 年度〜平成 11 年度, 1999 .

4) 宗谷管内ホタテ貝殼有効利用協議会: 風化貝を再生利 用するための指針，水質試験について，2006.

5) 椹木亨: 波と漂砂と構造物, 第 3 章 波と流れと漂砂, 技報堂出版， 1991 .

6) 西浜雄二: オホーツクのホタテ漁業, 北海道大学図書 刊行会, pp. 218, 1994.

7) 櫻井泉, 瀬戸雅文 : 楸殖ホタテガイの成長に適した流 動条件に関する実験的研究, 寒地技術論文集, 15 巻, pp. 381-384, 1999 .

8) 五嶋聖治, 千葉晋：オホーツク海における地まきホタ テガイの成長に関する試験研究 一ホタテガイの定位 におよぼす流向・流速の影響一, 水産学術研究・改良 補助事業報告 (平成 10 年度), 北水協会, pp. 60-64, 1999.

9) 五嶋聖治, 千葉晋：才ホーツク海における地まきホタ テガイの成長に関する試験研究 I . ホタテガイの成 長におよぼす流向・流速の影響に関する研究, 水産学 術研究・改良補助事業報告 (平成 11 年度), 北水協会, pp. 60-64, 2000. 